\title{
Integrating Information Technology (IT) into Accounting Courses
}

\author{
Dr. Ahmad N. Obaidat (Corresponding author) \\ Department of Accounting Chairman, Faculty of Administrative \& Financial Sciences \\ Tafila Technical University, Tafila, Jordan \\ P.O. Box: 179, Zip Code: 66110, Jordan \\ Tel: 96-27-7744-8845 E-mail: a_obaidat@yahoo.com \\ Rateb M. Alqatamin \\ Department of Accounting, Faculty of Administrative \& Financial Sciences \\ Tafila Technical University, Tafila, Jordan \\ P.O. Box: 179, Zip Code: 66110, Jordan
}

Tel: 96-27-9902-7867 E-mail: Rateb_qatamin@yahoo.com

Received: April 7, 2011 Accepted: June 2, $2011 \quad$ Published: October 1, 2011

doi:10.5539/ijbm.v6n10p205

URL: http://dx.doi.org/10.5539/ijbm.v6n10p205

\begin{abstract}
Given the wide range of Information Technologies (IT) available to use in accounting education, this study aims to investigate the accounting students' perceptions toward using IT in the learning process. Four tools of IT were used: Internet, Email, MS PowerPoint, and MS Excel. Also, this study aims to investigate whether these perceptions are affected by students' demographic factors. For these purposes, a questionnaire was designed and administered to 32 accounting students at the Faculty of Administrative and Financial Sciences at Tafila Technical University (TTU). The results showed that accounting students had positive perceptions toward the use of the four tools of IT in the learning process, and these perceptions were affected by the students' gender, access to Internet, and the average hours using the Internet.
\end{abstract}

Keywords: Information Technology, Internet, Email, MS PowerPoint, MS Excel, Learning process

\section{Introduction}

The rapid developments in Information Technology (IT) in the global business environment and in the learning process have created many challenges to the accounting profession as will as accounting educators. Mohamed and Lashine (2003) stated that the rapid spread and acceptance of globalization and the enormous developments in IT, have led to dramatic changes in the business environment, and these changes have brought new challenges not only to business but also to business education.

Calls have been made for changes in education in general and in accounting education in particular in terms of adopting IT in the learning process (Albrecht and Sack, 2000; Mohamed and Lashine, 2003, Mcvay, Murphy, \& Yoon, 2008).

However, there has not been much research focusing on the effect of IT on the learning process in Jordan. This study aims to investigate the perceptions of the accounting department students, at the Faculty of administrative and Financial Sciences at TTU, toward the use of IT in the learning process. Students experience four tools of IT in accounting courses which are: Internet, Electronic Mail (Email), Microsoft (MS) Power Point, and Microsoft (MS) Excel. Additional data about students' demographic factors have been considered, which are: Gender, Grade Point Average (GPA), having Personal Computer (PC), having access to Internet at home, average usage of PC, and average usage of Internet.

Accordingly, this study aims to answer the following questions:

Main Question: What are the accounting students' perceptions toward using the Internet, E-mail, MS PowerPoint, and MS Excel in the learning process? 
Secondary Question: Are there differences in students' perceptions toward the use of IT in the learning process due to: gender, GPA, owning PC, having access to Internet, and number of hours using the PC and Internet daily?

The following sections present the literature review, methodology and hypothesis, results of statistical analysis, and finally the study conclusions and discussion.

\section{Literature Review}

IT became very popular in academia because of its ease of use, structure and popularity among students. So, universities all over the world are investing in high-tech classrooms and pushing instructors to use more IT in their teaching (Sahin, 2009). And those who do not embrace technologies will likely find themselves left behind by their more IT-literate colleagues (Sangster \& Mulligan, 1997). The challenge to faculty is to keep up-to-date on the new tools that are available and find ways to use them in an appropriate and effective manner in their classes (Freeman, 2010).

A number of professional organizations have called for a change in accounting education (AECC, 1990; AAA, 1986; AICPA, 2006; AACSB, 2007; IMA, 1994). A common theme has been greater emphasis on the use of technology for instructional purposes (Ahadiat, 2008). Chang \& Hwang (2003) stated that educators recognize the importance of IT topics, but only a few IT topics can/will be covered in accounting curricula, and if accountants are not up-to-date on IT, they may not even be qualified to serve as business advisors.

Good educators have always used a mix of strategies to reach their objectives (Freeman, 2010), and they need to know about which technologies are appropriate for a variety of educational disciplines (Ahadiat, 2008).

Ahadiat (2008) revealed that the most frequently used application of technology was e-mail, which faculty used with a frequency of $90.2 \%$. The Internet was the second preferred application, chosen by nearly $90 \%$ of faculty. The next two preferred applications involved MS Excel with a frequency of $86 \%$, followed by MS PowerPoint with a frequency of $71 \%$. Also, Burke \& James (2008) conclude that MS PowerPoint lectures have become integral to instruction at most institutions, especially at colleges of business and in fields such as business communication. Because it allows integrating multimedia components such as graphics, sound, video, animations, and charts into their presentations, so making the information delivery process more efficient by supporting larger class sizes (Sahin, 2009).

Freeman (2010) asserted that today's internet-based tools can facilitate communication, interaction, and collaborative learning in ways that were not possible before. Haugland (2000) indicated that the use of computer instructional technology and course web pages enhance student's learning.

Marbach \& Sokolove (2002) revealed that E-mail allows instructors to offer personalized attention to students in meeting specific learning needs, and they provide an opportunity for students to ask for special help or additional information about class lectures and out-of-class assignments. It can supplement but cannot replace traditional communication modes. Sangster \& Mulligan (1997) found that the students have a positive perception toward the use of Internet and Email in accounting courses. And they consider the lectures supplemented with presentations as more effective, interesting, and helpful (Urbanová \& Čtrnáctová, 2009). Al-Momeni \& Al-Humod (1995) found that students at Qatar University and Yarmouk University consider MS Excel as the most appropriate application for accounting courses. Khaddash (2004) study showed that IT has a major role in serving the higher education in general and in accounting education in particular, and IT has a positive effect in terms of making the education more accessible, enhancing the level of education and reducing the educational cost. Finally, it can be assumed that tools of information and communication technologies will further penetrate into the teaching process (Urbanová \& Čtrnáctová, 2009)

\section{Methodology}

\subsection{Study Hypotheses}

This study aims to investigate the perceptions of the Accounting Department students toward the use of Email, Internet, MS PowerPoint, and MS Excel in the learning process, and if this perception is affected by students demographic factors. Accordingly, the hypotheses tested in this study were classified as main and secondary hypotheses as follows:

\subsubsection{Main Hypotheses:}

Hypothesis-M1: Accounting students have positive perceptions toward using the Internet in the learning process.

Hypothesis-M2: Accounting students have positive perceptions toward using the Email in the learning process. 
Hypothesis-M3: Accounting students have positive perceptions toward using the MS PowerPoint in the learning process.

Hypothesis-M4: Accounting students have positive perceptions toward using the MS Excel in the learning process.

3.1.2 Secondary Hypotheses:

Hypothesis-S1: There are statistical significant differences in students' perceptions toward the use of IT in the learning process due to gender.

Hypothesis-S2: There are statistical significant differences in students' perceptions toward the use of IT in the learning process due to GPA.

Hypothesis-S3: There are statistical significant differences in students' perceptions toward the use of IT in the learning process due to owning PC.

Hypothesis-S4: There are statistical significant differences in students' perceptions toward the use of IT in the learning process due to having access to Internet at home.

Hypothesis-S5: There are statistical significant differences in students' perceptions toward the use of IT in the learning process due to an average number of hours using the PC daily.

Hypothesis-S6: There are statistical significant differences in students' perceptions toward the use of IT in the learning process due to an average number of hours using the Internet daily.

\subsection{Study Sample}

This study concentrated on the department of accounting students at the Faculty of Administrative and Financial Sciences at Tafila Technical University (TTU) in Jordan. A sample of (32) students provided the primary data for this study. The students were in the third and fourth study years, because the use of IT in the courses concentrates on the third and fourth years of study.

\subsection{Instrument Development}

The study data were collected during the academic year 2010-2011 by using a questionnaire which consists of two sections. The first section included students' demographics: gender, study level, grand point average, owning $\mathrm{PC}$, average usage of PC daily, having access to Internet at home, and average usage of Internet daily. The second section included questions to measure accounting students' perceptions toward four tools of IT in the learning process: (1) Internet, (2) Email, (3) MS PowerPoint, and (4) MS Excel. The questionnaire used a 5-point Likert type scale with strongly agree; agree; undecided; disagree; and strongly disagree for the items of the second section of the questionnaire.

\subsection{Statistical Processing}

The study hypotheses were tested using descriptive statistics, one sample t-test, independent sample t-test, and one way ANOVA test, at (0.05) significance level.

\subsection{Study limits}

The result of this study is determined by the use of the study instrument and the population of the study, which consisted of the accounting department students at TTU, who were enrolled in the first term for the academic year 2010/2011.

\section{Results}

\subsection{Demographics}

Table (1) provides demographic information of the study sample. As shown, the sample consists of (32) accounting students, $(71.9 \%)$ of them were males, $(96.9 \%)$ of them were in the fourth study year, $(84.4 \%)$ of them owning PC at home, (28.1\%) of them have access to Internet at home.

\subsection{Hypotheses Test}

\subsubsection{One Sample T-test Results}

One sample T-test was used to test the main hypotheses (M1, M2, M3, and M4). Table (2) includes the statistical results for the first main hypothesis (M1). As shows the mean for this hypothesis is (4.2625) and it is significant $(\mathrm{t}=42.046, \mathrm{p}=0.000)$; therefore, this hypothesis is accepted, which means that accounting students have positive perceptions toward using the Internet in the learning process.

Table (3) includes the statistical results for the second main hypothesis (M2). As shown the mean for this 
hypothesis is (3.1302) and it is significant $(t=29.671, p=0.000)$; therefore, this hypothesis is accepted, which means that accounting students have positive perceptions toward using the Email in the learning process.

Table (4) includes the statistical results for the third main hypothesis (M3). As shown the mean for this hypothesis is (3.9375) and it is significant $(\mathrm{t}=45.839, \mathrm{p}=0.000)$; therefore, this hypothesis is accepted, which means that accounting students have positive perceptions toward using the MS PowerPoint in the learning process.

Table (5) includes the statistical results for the fourth main hypothesis (M4). As shown the mean for this hypothesis is (4.4948) and it is significant $(\mathrm{t}=54.050, \mathrm{p}=0.000)$; therefore, this hypothesis is accepted, which means that accounting students have positive perceptions toward using the MS Excel in the learning process.

\subsubsection{Independent Sample T-test Results}

Independent sample T-test was used to test the first, third, and fourth secondary hypotheses (S1, S3, and S4). Table (6) shows the statistical result for these hypotheses. As shown, female students have a greater mean (4.1444) than male students (3.8826) and this difference is significant $(t=-1.915, p=0.032)$; therefore, the first secondary hypothesis (S1) is accepted, which means that there are statistical significant differences in students' perceptions toward the use of IT in the learning process due to gender.

The results show that students owning PC have a greater mean (3.9685) than students who do not (3.8900), but this difference is not significant $(t=0.439, \mathrm{p}=0.332)$; therefore, the third secondary hypothesis $(\mathrm{S} 3)$ is rejected which mean that there are no statistical significant differences in students' perceptions toward the use of IT in the learning process due to owning PC.

The results also show that students having access to internet have a greater mean (4.1481) than students who do not (3.8812) and this difference is significant $(\mathrm{t}=2.622, \mathrm{p}=0.007)$; therefore, the fourth secondary hypothesis (S4) is accepted, which mean that there are statistical significant differences in students' perceptions toward the use of IT in the learning process due to having access to Internet at home.

\subsubsection{One Way ANOVA Test Results}

One way ANOVA test was used to test the second, fifth, and sixth secondary hypotheses (S2, S5, and S6). Descriptive statistics (Table 7) indicate that students with GPA less than (68\%), students with GPA between (68\%-76\%), and students with GPA more than (76\%) have means of (3.9333), (4.0500), and (3.8278) respectively. These differences are not significant as shown in table (8) $(f=0.513, p=0.604)$. Therefore, the second secondary (S2) hypothesis is rejected, which means that there are no statistical significant differences in students' perceptions toward the use of IT in the learning process due to GPA.

Descriptive statistics (Table 7) indicate that students using PC for less than (1) hour daily, students using PC between (1-2) hours daily, and students using PC for more than (2) hours daily have means of (3.9060), (3.8962), and (4.1512) respectively. These differences are not significant as shown in table $(8)(f=1.326, p=0.281)$. Therefore, the fifth secondary hypothesis (S5) is rejected, which means there are no statistical significant differences in students' perceptions toward the use of IT in the learning process due to an average number of hours using the PC daily.

Finally, table (7) shows that students using Internet for less than (1) hour daily, students using Internet between (1-2) hours daily, and students using Internet for more than (2) hours daily have means of (3.8438), (4.2896), and (4.2067) respectively. These differences are significant as shown in table $(8)(f=5.032, p=0.013)$. Therefore, the sixth secondary hypothesis (S6) is rejected, which means there are statistical significant differences in students' perceptions toward the use of IT in the learning process due to an average number of hours using the Internet daily. After determining the existence of significant differences, post hoc multiple comparisons were used to determine which means differ. Post Hoc Comparison (Table 9) indicates that the significant differences exist between students using Internet for less than (1) hour daily and students using Internet between (1-2) hours daily or for more than (2) hours daily.

\section{Conclusion and Discussion}

This study aims to investigate accounting students' perceptions toward the use of four IT tools in the learning process. These tools were the Email, Internet, MS PowerPoint, and MS Excel. Also this study aims to investigate whether students' perceptions are affected by students' demographic factors (gender, GPA, owning PC, having access to Internet, and average usage of PC and Internet).

The results indicated that accounting students consider the four IT tools necessary for the learning process which agrees with (Khaddash, 2004) study. MS Excel earned the highest positive perceptions by accounting students 
followed by Internet, MS PowerPoint, and Email respectively, which agrees with (Al-Humod \& Al-Momeni, 1995) study, which found that students at Qatar University and Yarmouk University consider MS Excel as the most appropriate application for accounting courses.

And this result may be interpreted by the nature of accounting as a practical science. Students considered MS Excel helpful in making mathematical calculations, preparing charts, preparing and presenting financial reports, and it is appropriate for practical courses.

Students considered the Internet an effective learning tool that allows them to get updated information required in the learning process in a manner that saves time and effort, and this result concurs with previous studies (Freeman, 2010; Sangster \& Mulligan, 1997).

MS PowerPoint was viewed as an appropriate tool to make learning shows for theoretical courses that help in increasing students' attention and in presenting shapes, forms, and financial reports, and this agrees with (Burke \& James; 2008, Sahin, 2009; Urbanová \& Čtrnáctová, 2009) studies, which conclude that MS PowerPoint lectures have become integral at business colleges, making lectures more effective, interesting, and helpful by allowing integrating multimedia components such as graphics, sound, video, animations, and charts.

Students also considered using Email to communicate with instructors helpful in the learning process in terms of saving time and efforts, and they usually use it to submit the homework or to make questions or queries, but they do not prefer using the Internet to communicate with instructors than meeting them, which concurs with (Marbach \& Sokolove, 2002; Sangster \& Mulligan, 1997) studies which found that the students have a positive perception toward the use of Email in accounting courses and it provides an opportunity for students to ask for special help or additional information, so it can supplement but cannot replace traditional communication modes.

Additional implications suggested by statistical results is that accounting students' perceptions toward the use of IT are affected by their demographic factors such as gender, having access to Internet at home and the average of hours using the Internet daily, but are not affected by other factors such as GPA, Owning PC, and the average of hours using PC daily. Female Students, students who have access to Internet at home, and students who use Internet for more than one hour daily have higher positive perception toward the use of IT in the learning process than male students, students who do not have access to Internet at home, and students who use Internet for less than one hour daily, respectively. Although the result concerning the effect of student gender on the perceptions toward IT did not agree with many previous studies (Sexton et. al., 1999; Hale, 2005) which conclude that female students have less favorable attitude toward IT, researchers have suggested that differences in use of technology between genders, ages, and levels of education may stem from socioeconomic and cultural issues (Ahadiat, 2008).

The findings may have been different if they had been related to accounting students in other universities or if they had been related to other tools of IT. These limitations highlight opportunities for further research to investigate the accounting students' perceptions toward using IT in the learning process.

\section{References}

Ahadiat, N. (2008). Technologies Used in Accounting Education: A Study of Frequency of Use Among Faculty. Journal of Education for Business, 123-133, January/February. http://dx.doi.org/10.3200/JOEB.83.3.123-134

Albrecht, W.S., and R.J. Sack. (2000). Accounting Education: Charting the Course through a Perilous Future. Sarasota: American Accounting Association.

Al-Humod, T., and Al-Momeni, M. (1995). Assessing Qatar University and Yarmouk University Experiment in using Computers in Accounting Education. Journal of Management and Economic Sciences, Special Issue, 36-60, October.

Burke, L., A., and James, K., E. (2008). PowerPoint-based Lectures in Business Education: an Empirical Investigation of Student-Perceived Novelty and Effectiveness. Business Communication Quarterly, 71(3), 227-296, September. http://dx.doi.org/10.1177/1080569908317151

Chang, C., J., and Hwang, N., R. (2003). Accounting education, firm training and information technology: a research note. Accounting Education, 12(4), 441-450, December. http://dx.doi.org/10.1080/0963928032000065557

Freeman, V., S. (2010). Focus: Online Education and Technology Introduction. Supplement Clinical Laboratory Science, 23(3), 51-52, Summer.

Hale, K. V. (2005). Gender differences in computer technology achievement. Meridian, 8, 1-4. 
Haugland, J., L. (2000). Using Computer Technology and Course Web Pages to Improve Student Performance in Accounting Courses. [Online] Available: http://frank.mtsu.edu/ itconf/proceed98/jhaugland.html.

Khaddash, H. (2004). Importance of using IT in Higher Education and Accounting Education in particular. Studies-Administrative Sciences, 31(2), 298-312.

Marbach-Ad, G., and Sokolove, P., G. (2002). The Use of E-Mail and In-Class Writing to Facilitate Student-Instructor Interaction in Large-Enrollment Traditional and Active Learning Classes. Journal of Science Education and Technology, 11(2), 109-119, June. http://dx.doi.org/10.1023/A:1014609328479

Mcvay, G. J., Murphy, P. R., and Yoon, S. W. (2008). Good Practices in Accounting Education: Classroom Configuration and Technological Tools for Enhancing the Learning Environment. Accounting Education: an international journal, 17(1), 41-63, March.

Mohamed, E. K. A., and Lashine, S. H. (2003). Accounting Knowledge and Skills and the Challenges of A Global Business Environment. Managerial Finance, 29(7), 3-16. http://dx.doi.org/10.1108/03074350310768319

Sahin, Y., Y. (2009). A comparison of graduate and undergraduate teacher education students' perceptions of their instructors' use of Microsoft PowerPoint, Technology. Pedagogy and Education, 18(3), 361-380, October.

Sangster, A., and Mulligan, C. (1997). Integrating the World Wide Web into an accounting systems course. Accounting Education, 6(1), 53-62. http://dx.doi.org/10.1080/096392897331631

Sexton, D., King, N., Albridge, J., and Goodstadt-Killoran, I. (1999). Measuring and evaluating early childhood prospective practitioners' attitudes toward computers. Family Relations, 48, 277-285. http://dx.doi.org/10.2307/585638

Urbanová, K., and Čtrnáctová, H. (2009). Efficiency of PowerPoint Presentation as a Component of Science Education. Problems of Education in the 21 Century, 17, 203-211.

Table 1. Demographic information

\begin{tabular}{|l|c|c|l|c|c|}
\hline Characteristic & Freq. & Percentage & Characteristic & Freq. & Percentage \\
\hline Gender & & & Having access to Internet & & \\
Male & 23 & $71.9 \%$ & Yes & 9 & $28.1 \%$ \\
Female & 9 & $28.1 \%$ & No & 23 & $71.9 \%$ \\
Total & 32 & $100 \%$ & Total & 32 & $100 \%$ \\
GPA & & & Average Use of PC & & \\
Less than 68\% & 20 & $62.5 \%$ & Less than one hour & 14 & $43.8 \%$ \\
Between 68\%-76\% & 9 & $28.1 \%$ & Between 1-2 hours & 11 & $34.4 \%$ \\
More than 76\% & 3 & $9.4 \%$ & More Than 2 hours & 7 & $21.9 \%$ \\
Total & 32 & $100 \%$ & Total & 32 & $100 \%$ \\
Student Level & & & Average Use of Internet & & \\
Third Year & 1 & $3.1 \%$ & Less than one hour & 23 & $71.9 \%$ \\
Forth Year & 31 & $96.9 \%$ & Between 1-2 hours & 4 & $12.5 \%$ \\
Total & 32 & $100 \%$ & More Than 2 hours & 5 & $15.6 \%$ \\
Owning PC & & & Total & 32 & $100 \%$ \\
Yes & 27 & $84.4 \%$ & & & \\
No & 5 & $15.6 \%$ & & & \\
Total & 32 & $100 \%$ & & \\
\hline
\end{tabular}


Table 2. One Sample T-test (Hypothesis-M1)

\begin{tabular}{|c|c|c|c|c|c|}
\hline No. & Item & Mean & Std. Dev. & t-value & p-value \\
\hline 1 & $\begin{array}{l}\text { Using Internet to get information saves time } \\
\text { and effort. }\end{array}$ & 4.6563 & 0.48256 & 54.583 & 0.000 \\
\hline 2 & $\begin{array}{l}\text { I consider the Internet as an effective learning } \\
\text { tool. }\end{array}$ & 3.9063 & 1.11758 & 19.772 & 0.000 \\
\hline 3 & $\begin{array}{l}\text { I use the Internet to get the data and information } \\
\text { required for the learning process. }\end{array}$ & 3.9688 & 0.99950 & 22.462 & 0.000 \\
\hline 4 & $\begin{array}{l}\text { Using the Internet helps in getting updated } \\
\text { information. }\end{array}$ & 4.5625 & 0.66901 & 38.578 & 0.000 \\
\hline 5 & $\begin{array}{l}\text { Internet is a necessary tool for the learning } \\
\text { process. }\end{array}$ & 4.2188 & 0.75067 & 31.791 & 0.000 \\
\hline Total & Internet & 4.2625 & 0.57347 & 42.046 & 0.000 \\
\hline
\end{tabular}

Table 3. One Sample T-test (Hypothesis-M2)

\begin{tabular}{|l|l|c|c|c|c|}
\hline No. & Item & Mean & Std. Dev. & t-value & p-value \\
\hline 1 & $\begin{array}{l}\text { Using Email to communicate with instructors } \\
\text { saves time and effort. }\end{array}$ & 3.6250 & 1.12880 & 18.166 & 0.000 \\
3 & $\begin{array}{l}\text { Using Email to communicate with instructors } \\
\text { helps in learning process. }\end{array}$ & 3.3750 & 0.87067 & 21.928 & 0.000 \\
4 & $\begin{array}{l}\text { I prefer using Email to communicate with } \\
\text { instructors than meting them personally. }\end{array}$ & 2.0000 & 0.95038 & 11.904 & 0.000 \\
5 & I use Email to submit the homework. & 3.5000 & 1.07763 & 18.373 & 0.000 \\
6 & $\begin{array}{l}\text { I use Email to ask questions or inquiries. } \\
\text { Email is a necessary tool for the learning } \\
\text { process. }\end{array}$ & 3.0938 & 1.08834 & 16.080 & 0.000 \\
\hline Total & Email & $\mathbf{3 . 1 3 0 2}$ & $\mathbf{0 . 5 9 6 7 9}$ & $\mathbf{2 9 . 6 7 1}$ & $\mathbf{0 . 0 0 0}$ \\
\hline
\end{tabular}

Table 4. One Sample T-test (Hypothesis-M3)

\begin{tabular}{|c|c|c|c|c|c|}
\hline No. & Item & Mean & Std. Dev. & t-value & p-value \\
\hline 1 & $\begin{array}{l}\text { MS PowerPoint facilitates making learning } \\
\text { shows. }\end{array}$ & 4.2813 & 0.58112 & 41.675 & 0.000 \\
\hline 2 & MS PowerPoint increases students' attention. & 4.0313 & 0.86077 & 26.493 & 0.000 \\
\hline 3 & $\begin{array}{l}\text { MS PowerPoint is appropriate for theoretical } \\
\text { courses. }\end{array}$ & 3.3750 & 1.23784 & 15.423 & 0.000 \\
\hline 4 & $\begin{array}{l}\text { MS PowerPoint helps to present all shapes } \\
\text { and forms. }\end{array}$ & 4.2813 & 0.52267 & 46.336 & 0.000 \\
\hline 5 & $\begin{array}{l}\text { MS PowerPoint helps in presenting financial } \\
\text { reports. }\end{array}$ & 3.8438 & 0.80760 & 26.924 & 0.000 \\
\hline 6 & $\begin{array}{l}\text { MS PowerPoint is a necessary tool for the } \\
\text { learning process. }\end{array}$ & 3.8125 & 0.82060 & 26.282 & 0.000 \\
\hline Total & MS PowerPoint & 3.9375 & 0.48591 & 45.839 & 0.000 \\
\hline
\end{tabular}

Table 5. One Sample T-test (Hypothesis-M4)

\begin{tabular}{|l|l|c|c|c|c|}
\hline No. & Item & Mean & Std. Dev. & t-value & p-value \\
\hline 1 & $\begin{array}{l}\text { MS Excel helps in making mathematical } \\
\text { calculations. }\end{array}$ & 4.9063 & 0.29614 & 93.718 & 0.000 \\
3 & $\begin{array}{l}\text { MS Excel facilitates preparing charts. } \\
\text { MS Excel is an appropriate tool for practical } \\
\text { courses. }\end{array}$ & 4.6563 & 0.54532 & 48.301 & 0.000 \\
4 & $\begin{array}{l}\text { MS Excel helps in preparing financial } \\
\text { reports. }\end{array}$ & 4.5313 & 0.78030 & 31.264 & 0.000 \\
5 & $\begin{array}{l}\text { MS Excel helps in presenting financial } \\
\text { reports. }\end{array}$ & 4.4063 & 0.83702 & 29.779 & 0.000 \\
6 & $\begin{array}{l}\text { MS Excel is a necessary tool for the learning } \\
\text { process. }\end{array}$ & 4.1563 & 0.76662 & 30.669 & 0.000 \\
\hline Total & MS Excel & $\mathbf{4 . 4 9 4 8}$ & $\mathbf{0 . 4 7 0 4 2}$ & $\mathbf{5 4 . 0 5 0}$ & $\mathbf{0 . 0 0 0}$ \\
\hline
\end{tabular}


Table 6. Independent Sample T-test (Hypotheses: S1, S3, S4)

\begin{tabular}{|l|l|c|c|c|c|c|}
\hline Independent Variable & Groups & $\mathrm{n}$ & Mean & Std. Dev. & t-value & p-value \\
\hline Gender & Male & 23 & 3.8826 & 0.30699 & \multirow{2}{*}{-1.915} & \multirow{2}{*}{0.032} \\
& Female & 9 & 4.1444 & 0.44062 & & \\
\hline Owning PC & Yes & 27 & 3.9685 & 0.35242 & \multirow{2}{*}{0.439} & \multirow{2}{*}{0.332} \\
& No & 5 & 3.8900 & 0.45133 & & \\
\hline Having access to Internet & Yes & 9 & 4.1481 & 0.18427 & \multirow{2}{*}{2.622} & \multirow{2}{*}{0.007} \\
& No & 23 & 3.8812 & 0.38948 & .62 & \\
\hline
\end{tabular}

Table 7. Descriptive Statistics (Hypotheses: S2, S5, S6)

\begin{tabular}{|l|l|l|l|l|l|}
\hline Independent Variable & \multicolumn{1}{|c|}{ Group } & \multicolumn{1}{c|}{ N } & \multicolumn{1}{c|}{ Mean } & Std. Dev. & Std. Error \\
\hline \multirow{5}{*}{$\boldsymbol{G P A}$} & Less Than 68\% & 20 & 3.9333 & 0.36196 & 0.08094 \\
& Between 68\%-76\% & 9 & 4.0500 & 0.41769 & 0.13923 \\
& More Than 76\% & 3 & 3.8278 & 0.15146 & 0.08744 \\
& Total & 32 & 3.9563 & 0.36234 & 0.06405 \\
\hline \multirow{5}{*}{ Hours using PC } & Less than (1) hour & 14 & 3.9060 & 0.40567 & 0.10842 \\
& Between (1-2) hours & 11 & 3.8962 & 0.36415 & 0.10979 \\
& More than (2) hours & 7 & 4.1512 & 0.20958 & 0.07921 \\
& Total & 32 & 3.9563 & 0.36234 & 0.06405 \\
\hline \multirow{5}{*}{ Hours using Internet } & Less than (1) hour & 23 & 3.8438 & 0.33718 & 0.07031 \\
& Between (1-2) hours & 4 & 4.2896 & 0.32577 & 0.16289 \\
& More than (2) hours & 5 & 4.2067 & 0.22464 & 0.10046 \\
& Total & 32 & 3.9563 & 0.36234 & 0.06405 \\
\hline
\end{tabular}

Table 8. One way ANOVA test (Hypotheses: S2, S5, S6)

\begin{tabular}{|l|l|c|c|c|c|c|}
\hline $\begin{array}{l}\text { Independent } \\
\text { Variable }\end{array}$ & \multicolumn{1}{|c|}{ Variance } & $\begin{array}{c}\text { Sum of } \\
\text { Squares }\end{array}$ & df & $\begin{array}{c}\text { Mean } \\
\text { Square }\end{array}$ & F & Sig. \\
\hline \multirow{G}{*}{$\boldsymbol{A}$} & Between Groups & 0.139 & 2 & 0.070 & & \\
& Within Groups & 3.931 & 29 & 0.136 & 0.513 & 0.604 \\
& Total & 4.070 & 31 & & & \\
\hline \multirow{3}{*}{ Hours using $\boldsymbol{P C}$} & Between Groups & 0.341 & 2 & 0.171 & & \\
& Within Groups & 3.729 & 29 & 0.129 & 1.326 & 0.281 \\
& Total & 4.070 & 31 & & & \\
Hours using & Between Groups & 1.049 & 2 & 0.524 & & \\
Internet & Within Groups & 3.021 & 29 & 0.104 & 5.032 & 0.013 \\
\hline
\end{tabular}

Table 9. Multiple Comparisons LSD (Hypotheses-S6)

\begin{tabular}{|l|l|c|c|c|}
\hline (I) Group & $(J)$ Group & Mean Difference (I-J) & Std. Error & Sig. \\
\hline Less than (1) hour & Between (1-2) hours & $-0.44574(*)$ & 0.17486 & 0.016 \\
& More than (2) hours & $-0.36283(*)$ & 0.15927 & 0.030 \\
Between (1-2) hours & Less than (1) hour & $0.44574(*)$ & 0.17486 & 0.016 \\
& More than (2) hours & 0.08292 & 0.21653 & 0.705 \\
\hline
\end{tabular}

